\title{
A comparison of the effects of 2 cattle-cooling systems on dairy cows in a desert environment
}

\author{
X. A. Ortiz, ${ }^{*}$ J. F. Smith, ${ }^{* 1}$ B. J. Bradford, ${ }^{*}$ J. P. Harner, $†$ and A. Oddy \\ *Department of Animal Sciences and Industry and \\ †Department of Biological and Agricultural Engineering, Kansas State University, Manhattan 66502 \\ ‡NADA Al-Othman, Al Ahsa, Saudi Arabia 31982
}

\section{ABSTRACT}

An experiment was conducted to investigate the effects of operation time and size of Korral Kool (KK; Korral Kool Inc., Mesa, AZ) systems on core body temperature (CBT) of dairy cows. Two KK systems were compared: a system with 1.29-m-diameter, 3-hp fans spaced $6 \mathrm{~m}$ apart (referred to as small) and a system with 1.52-m-diameter, 5 -hp fans spaced $8 \mathrm{~m}$ apart (referred to as big). Forty-eight multiparous Holstein cows were assigned randomly to 8 pens ( 4 big, 4 small), and pens were assigned randomly to a sequence of treatments (KK operated for 21 or $24 \mathrm{~h} / \mathrm{d}$ ) in a switchback design. A complementary calorimetric analysis was developed to investigate the cooling area under the KK units of the big and small systems. Twenty-five sensors distributed equally under the KK units measured ambient temperature at 5-min intervals for $2 \mathrm{~h}$. Average ambient temperature was $35.0 \pm 0.6^{\circ} \mathrm{C}$ and relative humidity was $45 \pm 8 \%$. There were significant treatment effects on mean CBT: cows on the small 24-h treatment had a lower mean CBT than cows on the small 21-h treatment $\left(39.22\right.$ vs. $\left.39.36 \pm 0.14^{\circ} \mathrm{C}\right)$, and cows on the big 24-h treatment had a lower mean CBT than cows on the big 21 -h treatment $\left(38.95\right.$ vs. $\left.39.09 \pm 0.13^{\circ} \mathrm{C}\right)$. A significant treatment by time interaction was observed. The greatest difference between systems occurred at $0100 \mathrm{~h}$; treatment means at this time were 39.05, 39.01, 39.72 , and $39.89 \pm 0.16^{\circ} \mathrm{C}$ for the big 24-h, big 21-h, small 24-h, and small 21-h treatments, respectively. At certain times of day, the big system reduced CBT more than the small system. These results show that CBT of multiparous cows decreased when KK system operational time was increased from 21 to $24 \mathrm{~h}$ regardless of the size of the KK cooling system used. The calorimetric analysis showed that even though the big system resulted in lower mean ambient temperatures than the small system, the distance between units in

Received February 1, 2010.

Accepted June 7, 2010.

${ }^{1}$ Corresponding author: jfsmith@ksu.edu the big system should be decreased to reduce the variation in temperature under the big units.

Key words: heat stress, dairy cow, evaporative cooling

\section{INTRODUCTION}

The negative effects of heat stress on dairy cattle are well documented (Kadzere et al., 2002; West et al., 2003). In past years, a great effort has been made to evaluate different cooling systems for heat-stressed cows. Little research has been conducted to compare different methods of operating these cooling systems on commercial dairy farms in arid climates.

Evaporative cooling is an efficient cooling method in desert environments because of the high ambient temperatures and low relative humidity. The Korral Kool (KK; Korral Kool Inc., Mesa, AZ) system is a type of evaporative cooling system that consists of highpressure misters injecting fine fog into the air and fans driving air through vanes to create a cyclonic motion of air down to the cows. This system uses convection and evaporation pathways to increase the dissipation of heat from the cow to the environment.

On most dairy farms, KK systems are set to start at an ambient temperature of $27^{\circ} \mathrm{C}$. At this temperature, the thermoneutral zone ( TNZ) of a dairy cow $\left(20^{\circ} \mathrm{C}\right.$; NRC, 2001) has been exceeded. This suggests that KK systems should be set to work on the basis of the TNZ of dairy cows. Yet, because ambient temperature in arid environments is often higher than the TNZ for dairy cows, we hypothesized that KK systems should work on the basis of operation time.

Two sizes of KK systems are available: a small system with 1.29-m-diameter, 3-hp fans and a big system with 1.52 -m-diameter, 5 -hp fans. Because of the difference in size, these systems have different expected decreases in the air temperature surrounding cows. The small system has an expected decrease in temperature between 8 and $16^{\circ} \mathrm{C}$, whereas the big system has an expected decrease in temperature between 8 and $19^{\circ} \mathrm{C}$.

Previous experiments demonstrated that in arid climates, continuous operation of 1.29-m-diameter 
KK units reduced the core body temperature (CBT) of multiparous cows (Ortiz et al., 2009). Core body temperature is an indicator used to assess the physiological response to high thermal stress in dairy cows. Under normal conditions, the mean CBT of dairy cows is $38.6^{\circ} \mathrm{C}$ (Dukes, 1947; Settivari et al., 2007).

The objective was to investigate the effects of 2 sizes of KK systems and 2 operating times on CBT of lactating Holstein dairy cows housed in desert barns in an arid climate where ambient temperature exceeds the TNZ $24 \mathrm{~h} / \mathrm{d}$.

\section{MATERIALS AND METHODS}

Experimental procedures were approved by the Institutional Animal Care and Use Committee at Kansas State University (Manhattan). An experiment was conducted on a commercial dairy farm near Al-Ahsa, Saudi Arabia. Cows were housed in desert barns with a covered area of $10 \mathrm{~m}^{2} /$ cow covering the feeding area and part of the dry lot.

Pens had 1 of 2 types of KK systems (Korral Kool, Mesa, AZ) located in openings on the roof. The first system (referred to as small) had 1.29-m diameter, 3-hp motors and units were placed at $6-\mathrm{m}$ intervals. The second system (referred to as big) had 1.52-m diameter, 5 -hp motors and units were placed at 8 -m intervals. Weighted curtains were placed on the sides of the desert barns of all pens to keep the cooled air inside the shaded area. All Korral Kool units were inspected before the trial to ensure that they were operating correctly.

Ambient temperature and relative humidity outside the barns were measured every 15 min with 6 weather stations located throughout the farm. Weather stations were composed of a sensor (HOBO Pro H8, Onset Computer Corporation, Bourne, MA) and a solar radiation shield (M-RSA, Onset Computer Corporation). Core body temperature measurements were obtained at 5-min intervals with data loggers (HOBO U12, Onset Computer Corporation) attached to blank continuous intravaginal drug release devices (Pfizer Animal Health, New York, NY). This experiment lasted 6 d, with 3 periods of $2 \mathrm{~d}$ each. Cows had $1 \mathrm{~d}$ to acclimate to each treatment, and only the CBT data from the second day was analyzed to minimize carryover effects between treatments.

Because of the short duration of these experiments, DMI and milk yield of the animals were not analyzed. This decision was based on a study that indicated that black globe temperatures 24 to $48 \mathrm{~h}$ prior were associated with reduced milk production (Collier et al., 1981). All animals were milked 4 times daily at 0600, 1200, 1800, and $0000 \mathrm{~h}$. In this experiment, 2 milking parlors were used. Cows with small units in the housing area were milked in a milking parlor cooled by continuously operating small units in the holding pen. Cows housed in pens with big units were milked in a milking parlor cooled by continuously operating big units in the holding pen. Cows in both parlors were cooled in the exit lanes by a soaker system activated as cows exited the milking parlors. Milking parlors had the same milking times.

The 2 sizes (small and big) of KK units were operated for 21 or $24 \mathrm{~h} / \mathrm{d}$ while CBT of 48 multiparous (mean milk production $=33 \mathrm{~kg} / \mathrm{d} ; \mathrm{DIM}=112$ ) Holstein dairy cows were monitored. Animals were housed in 8 different pens, with 6 cows per pen and 4 pens per KK system. Pens were assigned randomly to a treatment sequence in a switchback design. All treatments started at $0600 \mathrm{~h}$, and systems for the 21-h treatments were turned off at $0300 \mathrm{~h}$.

A calorimetric analysis was conducted simultaneously to compare the cooling areas under the KK units of the big and the small systems. Twenty-five sensors (HOBO Pro H8, Onset Computer Corporation) that measured ambient temperature inside the barns at 5-min intervals were placed according to a grid distribution (Figure 1) under 3 small units and 3 big units operated continuously. These sensors were placed $1 \mathrm{~m}$ above the bedding area and measured ambient temperature for a period of $2 \mathrm{~h}$ in each system. Because both studies were conducted simultaneously, the KK units used for the calorimetric analysis were not the same units used for the operation time study. Ambient temperature data inside the barn were analyzed by using Surfer software (Surfer 8, Golden Software Inc., Golden, CO) to create calorimetric graphs of both systems.

\section{Statistical Analysis}

Vaginal temperature data were analyzed using a repeated measures model of SAS (version 9.1, SAS Institute, Cary, NC) according to the following model:

$Y_{i j k}=\mu+T_{i}+P_{j}+C_{k}\left(P_{j}\right)+D_{l}+H_{m}+T_{i} H_{m}+e_{i j k}$, where $Y_{\mathrm{ijk}}=$ an individual data point, $\mu=$ overall mean, $\mathrm{T}_{\mathrm{i}}=$ fixed effect of treatment ( $\mathrm{i}=1$ to 4$), \mathrm{P}_{\mathrm{j}}=$ random effect of pen ( $\mathrm{j}=1$ to 8$), \mathrm{C}_{\mathrm{k}}\left(\mathrm{P}_{\mathrm{j}}\right)=$ random effect of cow within pen ( $\mathrm{k}=1$ to 6$), \mathrm{D}_{1}=$ random effect of day (1 $=1$ to 3$), H_{m}=$ fixed effect of time $(\mathrm{m}=1$ to 24$)$, and $\mathrm{e}_{\mathrm{ijk} k \mathrm{~m}}=$ residual error. Treatment effects were tested by the PDIFF option and were declared significant at $P$ $<0.05$.

\section{RESULTS}

During the experiment, average ambient temperature was $35.0 \pm 0.6^{\circ} \mathrm{C}$ and average relative humidity was 45 


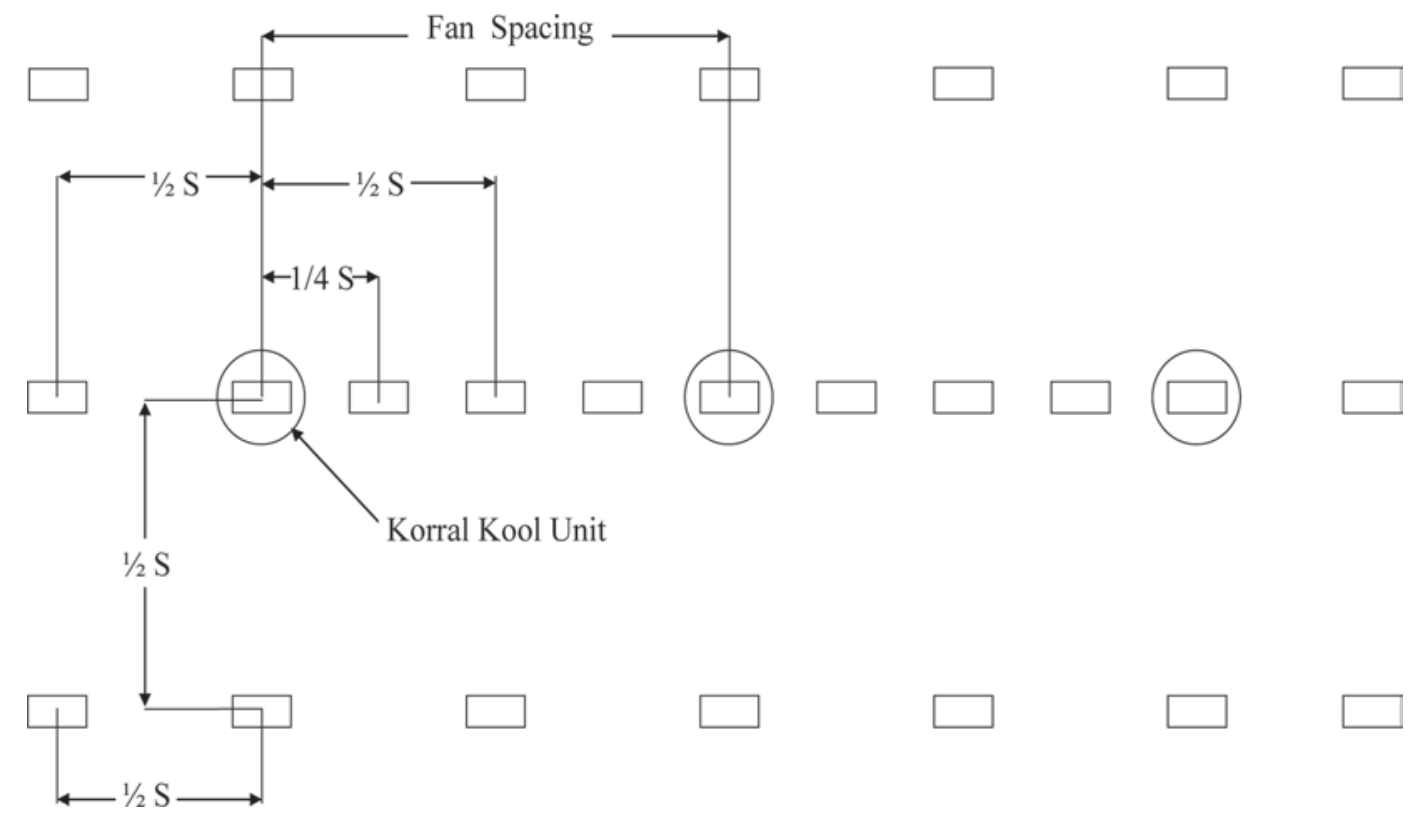

Figure 1. Distribution of the sensors under 3 Korral Kool units (Korral Kool Inc., Mesa, AZ) in the small (1.29-m diameter, 3-hp motors, distance of $6 \mathrm{~m}$ between units) and big (1.52-m diameter, 5-hp motors, distance of $8 \mathrm{~m}$ between units) Korral Kool systems that measured ambient temperature at 5-min intervals.

$\pm 8 \%$ (Figure 2). Because of the distribution grid used for the calorimetric analysis, the area analyzed for the small and big systems was 108 and $192 \mathrm{~m}^{2}$, respectively. Mean ambient temperature inside the desert barn cooled with the small system was $29.5 \pm 0.6^{\circ} \mathrm{C}$, compared with $26.8 \pm 0.4^{\circ} \mathrm{C}$ inside the desert barn cooled with the big system.

The calorimetric distribution of the area under the big system is illustrated in Figure 3. The maximum and minimum ambient temperatures inside the barn were 31.8 and $23.9^{\circ} \mathrm{C}$, respectively. The lowest temperatures were registered at $2 \mathrm{~m}$ around the KK units. The highest temperatures were observed at $4 \mathrm{~m}$ around the units and at the area next to the curtains. On the basis of this information, each $\mathrm{KK}$ unit in the big system provided $7.77 \mathrm{~m}^{2}$ of cooled area under $25^{\circ} \mathrm{C}$.

The calorimetric distribution of the area under the small system is illustrated in Figure 4. The maximum

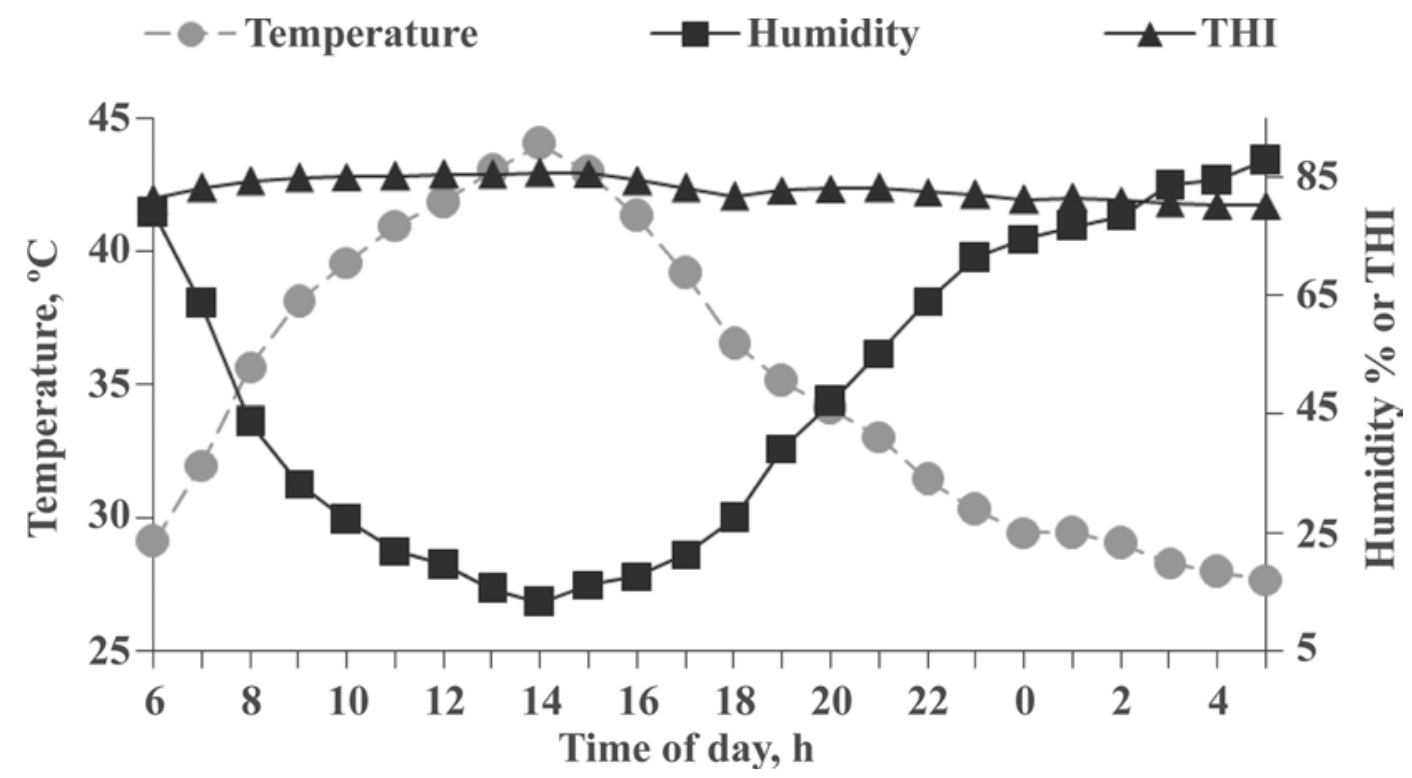

Figure 2. Average ambient temperature humidity index (THI), temperature, and relative humidity by hour of the day. 


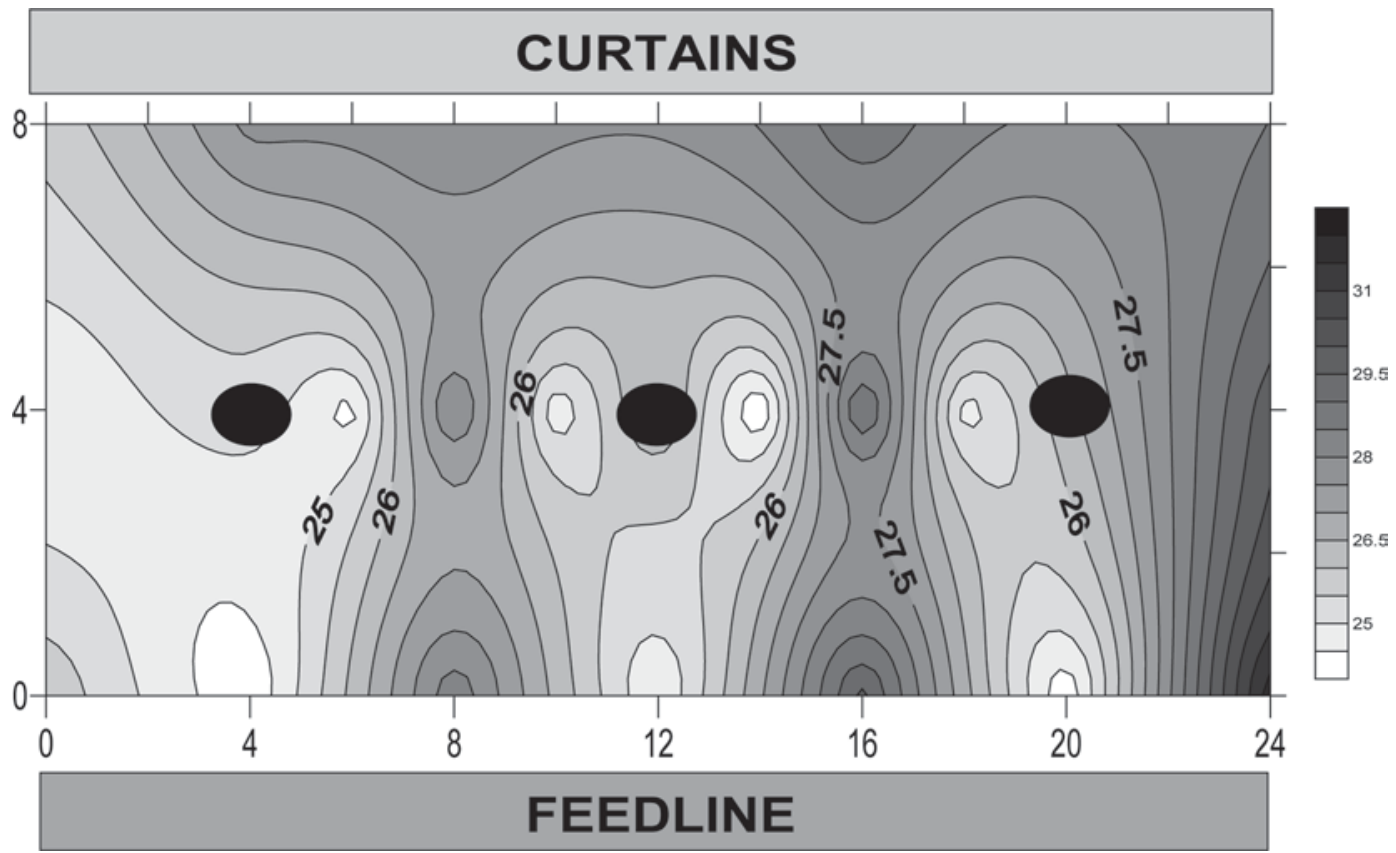

Figure 3. Calorimetric distribution of the area under the big Korral Kool (Korral Kool Inc., Mesa, AZ) units (1.52-m diameter, 5-hp motors, distance of $8 \mathrm{~m}$ between units).

and minimum ambient temperatures inside the barn were 32.9 and $26.9^{\circ} \mathrm{C}$, respectively. On the basis of these results, the small system did not provide a cooled area under $25^{\circ} \mathrm{C}$. However, these results need to be interpreted carefully because of the temperature variation observed in the small system.

Treatment effects on CBT are shown in Figure 5. There were significant treatment effects on mean CBT: cows on the small 24-h treatment had a lower mean CBT $(P<0.03)$ than cows on the small 21 -h treatment $\left(39.22\right.$ vs. $\left.39.36 \pm 0.14^{\circ} \mathrm{C}\right)$, and cows on the big 24 -h treatment had a lower mean CBT $(P<0.02)$ than cows on the big 21 -h treatment $\left(38.95\right.$ vs. $\left.39.09 \pm 0.13^{\circ} \mathrm{C}\right)$. The difference in CBT between the big and small systems was not statistically significant $(P<0.13)$.

There was a significant treatment by time interaction $(P<0.001)$. The greatest treatment effects occurred at $0100 \mathrm{~h}$; treatment means at this time were $39.05,39.01$, 39.72 , and $39.89 \pm 0.16^{\circ} \mathrm{C}$ for the big 24 -h, big 21$\mathrm{h}$, small 24-h, and small 21-h treatments, respectively (Figure 6). At certain times of day, the big system performed better than the small system in terms of cooling.

\section{DISCUSSION}

The TNZ for dairy cows is between 5 and $20^{\circ} \mathrm{C}$. Mild heat stress can reduce DMI and increase maintenance requirements (NRC, 2001), and these effects are accentuated at $25^{\circ} \mathrm{C}$ (McDowell, 1972). Rhoads et al.
(2009) suggested that decreases in milk production are the result of a reduction in DMI in combination with changes in nutrient partitioning.

On commercial dairy farms in arid climates, the ambient temperature during summer months exceeds TNZ conditions, meaning that appropriate mitigation measures must be used to alleviate heat stress. At high ambient temperatures heat dissipation from the cow to the environment depends on evaporation. It was estimated that at $30^{\circ} \mathrm{C}$, approximately $85 \%$ of the total evaporative heat loss of lactating cows is through evaporation from the skin and $15 \%$ is through panting (Maia et al., 2005).

The KK system improved the environment of dairy cows housed in desert environments. Ryan et al. (1992) observed an increase in reproductive performance and milk yield of cows housed with the KK system. But although this system is widely used on dairy farms around the world, little is known about how it should be operated on commercial dairy farms. Previous research showed that small KK systems should be operated continuously to decrease the CBT of multiparous cows (Ortiz et al., 2009).

The results from the present experiment showed a significant decrease in CBT when both sizes of $\mathrm{KK}$ systems were operated for 24 vs. $21 \mathrm{~h} / \mathrm{d}$. These results suggest that KK systems in arid environments should be operated continuously for multiparous cows when ambient conditions exceed the TNZ. 


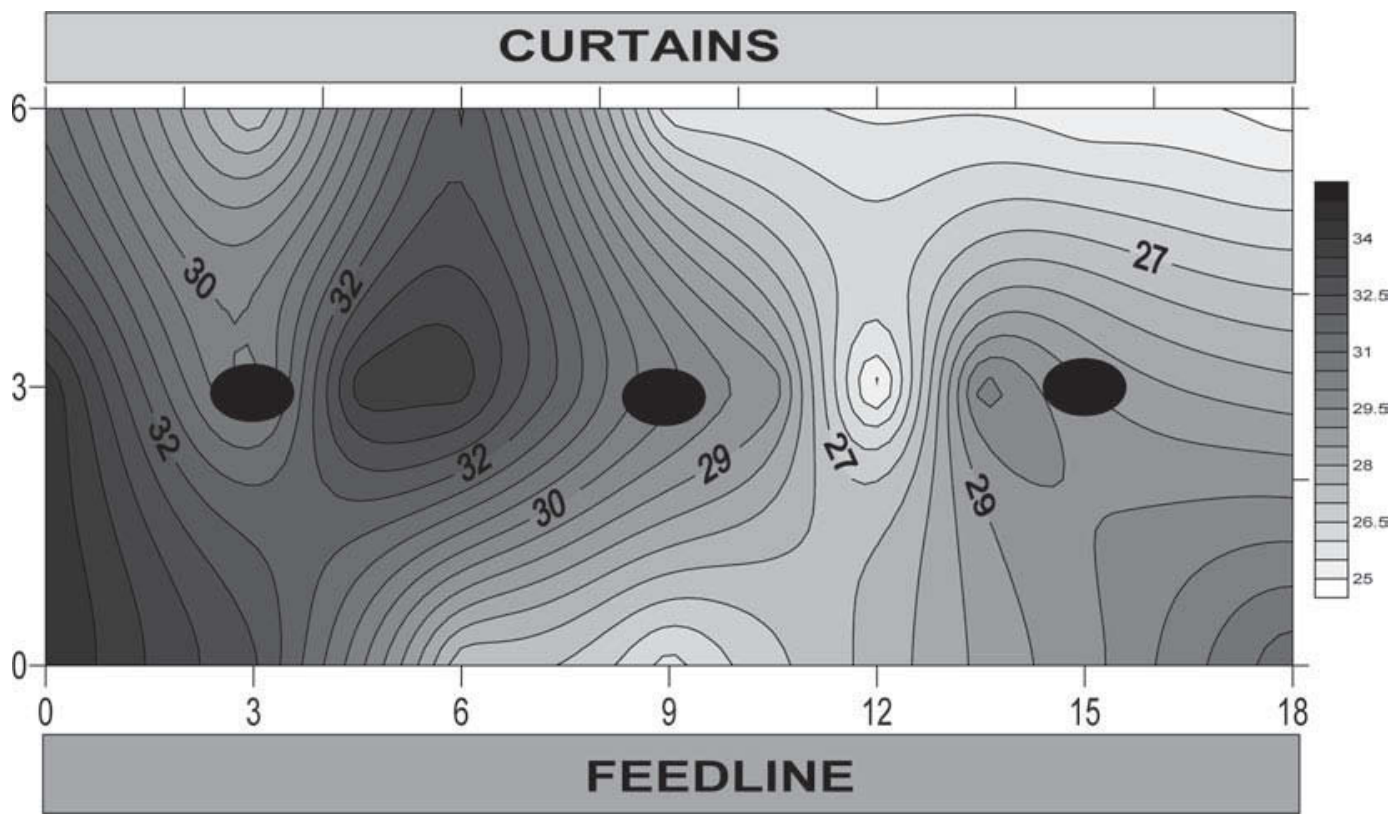

Figure 4. Calorimetric distribution of the area under small Korral Kool (Korral Kool Inc., Mesa, AZ) units (1.29-m diameter, 3-hp motors, distance of $6 \mathrm{~m}$ between units).

Additionally, a significant treatment by time interaction was observed between the $2 \mathrm{KK}$ systems. This difference might be attributed to the additional cooling in the holding pen in the big system. Armstrong (1994) reported that holding pens were the most stressful area in a dairy farm because of the lack of ventilation and the amount of time cows spent waiting to be milked. Ambient temperature in the holding pens was not measured in the present experiment; however, major differences in the CBT of animals housed with the small and big systems were observed after cows were milked. Cows were milked 4 times daily at 0000, 0600, 1200, and 1800 $\mathrm{h}$. At each milking, cows remained at the milking parlor for approximately $1 \mathrm{~h}$ before returning to their respective pens. As seen in Figure 6, the differences in CBT between the small and big systems occurred during and after milking time, suggesting that at milking times, the big system reduced CBT compared with the small system.

Results from the calorimetric analysis demonstrated the small system had a higher mean ambient temperature inside the barn than the big system. The lowest temperatures in the big system occurred at $2 \mathrm{~m}$ around the units. The highest temperatures in the big system were observed at $4 \mathrm{~m}$ between the units, suggesting that it might be advantageous to place units in the big system less than $8 \mathrm{~m}$ apart to create a more homogeneous cooled area under the shade.

\section{CONCLUSIONS}

The CBT of multiparous cows decreased when KK system operating time was increased from 21 to $24 \mathrm{~h}$ regardless of the size of the KK system. The big system resulted in lower mean ambient temperatures inside the barn compared with the small system. It might be advantageous to reduce the distance between units in the big system to $7 \mathrm{~m}$ to reduce the variation in temperature between units.

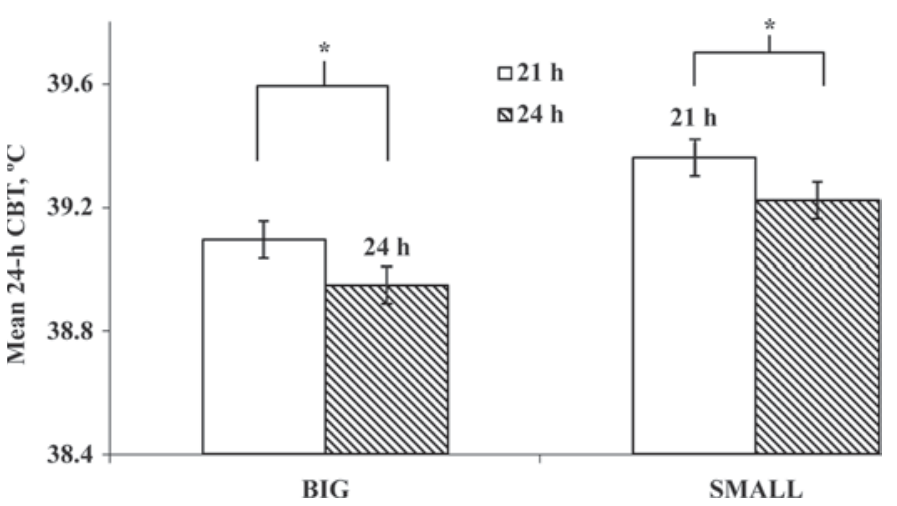

Figure 5. Mean core body temperature (CBT) of multiparous cows housed under small (1.29-m diameter, 3-hp motors, distance of $6 \mathrm{~m}$ between units) or big (1.52-m diameter, 5-hp motors, distance of 8 $\mathrm{m}$ between units) Korral Kool systems (Korral Kool Inc., Mesa, AZ) operated for 21 or $24 \mathrm{~h} / \mathrm{d}$. Bars represent SEM $(\mathrm{n}=24)$. The contrast between the big and small systems was not statistically significant $(P$ $=0.13) ; * P<0.05$ 


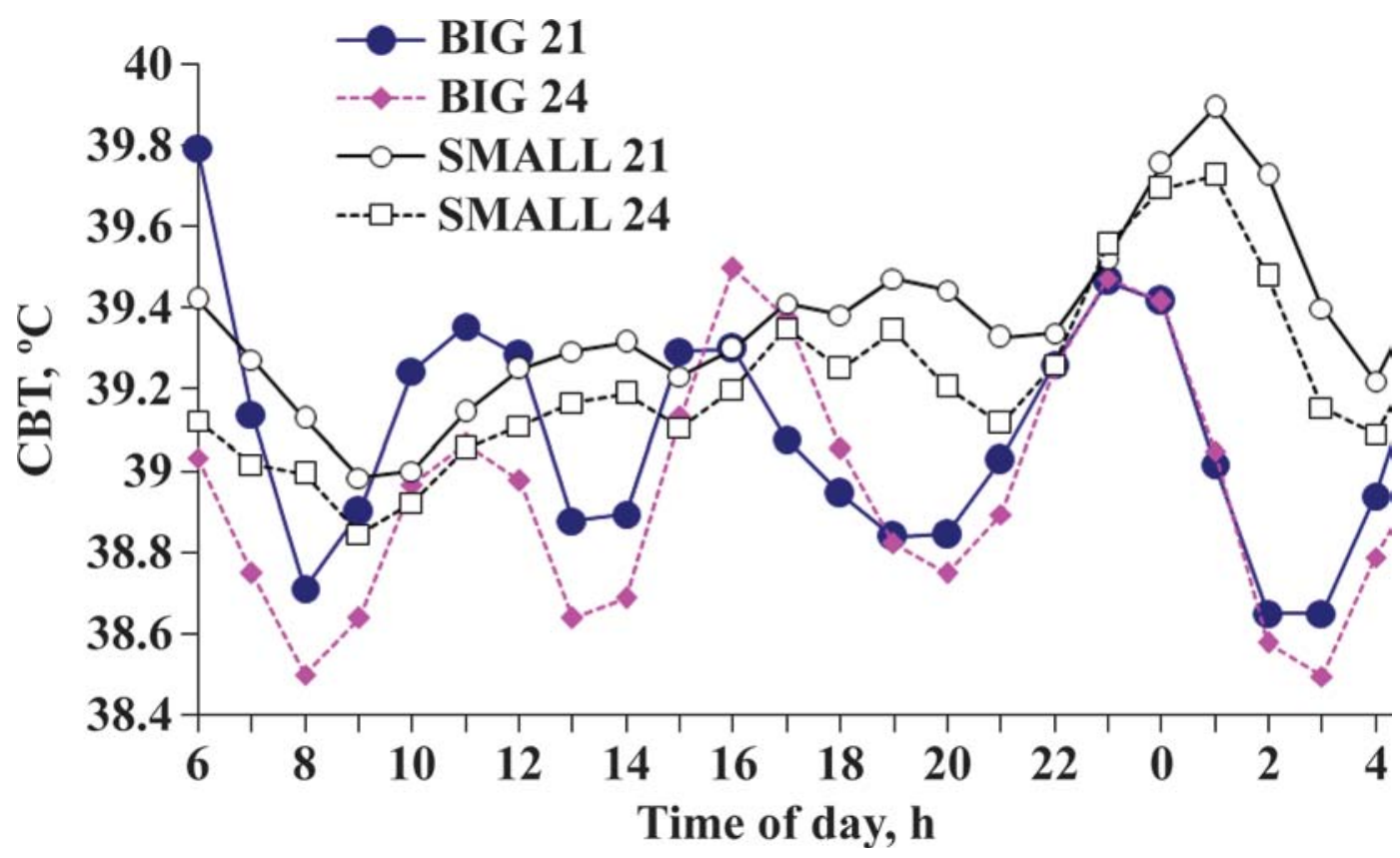

Figure 6. Continuous core body temperature (CBT) of multiparous cows housed under small (1.29-m diameter, 3-hp motors, distance of $6 \mathrm{~m}$ between units) and big (1.52-m diameter, 5-hp motors, distance of $8 \mathrm{~m}$ between units) Korral Kool systems (Korral Kool Inc., Mesa, AZ) operated for 21 or $24 \mathrm{~h} / \mathrm{d}$. Treatment by time interaction: $P<0.001$. SEM $=0.06 ; \mathrm{n}=24$. Color version available in the online PDF.

\section{ACKNOWLEDGMENTS}

The authors express their appreciation to NADA AlOthman (Al Ahsa, Saudi Arabia) for their support in the development of this experiment.

\section{REFERENCES}

Armstrong, D. V. 1994. Heat stress interaction with shade and cooling. J. Dairy Sci. 77:2044-2050.

Collier, R. J., R. M. Eley, A. K. Sharma, R. M. Pereira, and D. E. Buffington. 1981. Shade management in subtropical environment for milk yield and composition in Holstein and Jersey cows. J. Dairy Sci. 64:844-849.

Dukes, H. H. 1947. The Physiology of Domestic Animals. 6th ed. Comstock Publishing Company Inc., Ithaca, NY.

Kadzere, C. T., M. R. Murphy, N. Silanikove, and E. Maltz. 2002. Heat stress in lactating dairy cows: A review. Livest. Prod. Sci. 77:59-91

Maia, A. S. C., R. G. daSilva, and C. M. Battiston Loureiro. 2005. Sensible and latent heat loss from the body surface of Holstein cows in a tropical environment. Int. J. Biometeorol. 50:17-22.
McDowell, R. E. 1972. Improvement of Livestock Production in Warm Climates. W. H. Freeman \& Co., San Francisco, CA.

National Research Council. 2001. Nutrient Requirements of Dairy Cattle. 7th ed. Natl. Acad. Sci., Washington, DC.

Ortiz, X. A., J. F. Smith, B. J. Bradford, J. P. Harner III, and A. Oddy. 2009. Effects of Korral Kool ${ }^{\circledR}$ running time on core body temperature of dairy cows in a desert environment. J. Dairy Sci. 92:2356-2357. (Abstr.).

Rhoads, M. L., R. P. Rhoads, M. J. VanBaale, R. J. Collier, S. R. Sanders, W. J. Weber, B. A. Crooker, and L. H. Baumgard. 2009. Effects of heat stress and plane of nutrition on lactating Holstein cows: I. Production, metabolism, and aspects of circulating somatotropin. J. Dairy Sci. 92:1986-1997.

Ryan, D. P., M. P. Boland, E. Kopel, D. Armstrong, L. Munyakazi, R. A. Godke, and R. H. Ingraham. 1992. Evaluating two different evaporative cooling management systems for dairy cows in a hot, dry climate. J. Dairy Sci. 75:1052-1059.

Settivari, R. S., J. N. Spain, M. R. Ellersieck, J. C. Byatt, R. J. Collier, and D. E. Spiers. 2007. Relationship of thermal status to productivity in heat-stressed dairy cows given recombinant bovine somatotropin. J. Dairy Sci. 90:1265-1280.

West, J. W., B. G. Mullinix, and J. K. Bernard. 2003. Effects of hot, humid weather on milk temperature, dry matter intake, and milk yield of lactating dairy cows. J. Dairy Sci. 86:232-242. 